\title{
LA ACEDIA EN EL DECADENTISMO FINISECULAR DE HUYSMANS
}

\author{
THE ACEDIA IN THE FINISECULAR DECADENTISM OF HUYSMANS
}

\author{
Ainhoa Segura Zariquiegui \\ Universidad de Burgos \\ aszariquiegui@ubu.es
}

\section{RESUMEN}

El Decadentismo es una corriente artística que nace a finales de siglo XIX en Francia (muy asociada a la figura de Baudelaire) y de allí se despliega al resto del mundo occidental. La obra en la que se basa este estudio es A contrapelo (À rebours) de Joris-Karl Huysmans. La trama tiene muchas coincidencias con la vida de Beckford, (uno de los dandis más legendarios) y trata sobre el duque Floressas des Esseintes que se instala en un castillo para vivir en soledad. Su existencia sibarítica y decadente se va haciendo cada vez más lúgubre debido al spleen acidioso que padece hasta que vuelve a París para curarse de su estado melancólico. En este artículo se van a analizar las conexiones entre la acedia medieval de los monjes y el Decadentismo finisecular de Huysmans, utilizando la obra À revours de Huysmans como marco de estudio.

PALABRAS Clave: Literatura finisicular; Decadentismo; melancolía; Huysmans.

\section{Abstract}

The Decadent Literature is an artistic style that was born at the end of the nineteenth century in France (very associated with Baudelaire) and from there it unfolds to the rest of the Western world. This article is based in Joris-Karl Huysmans (A contrapelo). The plot has many coincidences with the life of Beckford, one of the most legendary dandies. It is 
about an old dandy, the Duke Floressas des Inseines, which settles in a castle to live in solitude. His existence became more and more sad because of the spleen he suffers. The features on the acedia of the Decadent literature will be analyzed in this article.

KEY WORDS: Finisicular literature; Decadent Literature; Melancholy; Huysmans.

Joris Karl Huysmans (1848-1907) inició su trayectoria literaria con el Naturalismo de Zola, pero pronto se alejó de este círculo con obras como À vau l'eau (1882) y À rebours (1884), novela fetiche del Decadentismo. Este periodo terminó con En Rade (1887) donde profundiza en un mundo onírico y lleno de fantasía y con Là Bas (1891), novela dedicada a la seducción del satanismo. Posteriormente, el autor se convirtió en un católico ferviente cuya inspiración mística produjo sus obras finales, En route (1895), Le Cathédrale (1898) y L’Oblat (1903). Respecto a À rebours, M. González señala:

Esta obra, considerada la 'Biblia del Decadentismo', apareció publicada por primera vez en 1884 y supuso una auténtica conmoción en el mundo de las letras francesas: por un lado, rompió con el Naturalismo de Zola, potenciando frente a este, lo exquisito, lo refinado, hasta el delirio, la singularidad más extrema: por otro exaltó el decadentismo estético de los jóvenes escritores franceses, que hicieron de ella su obra de referencia y por último, provocó el espanto de los círculos literarios oficiales, que defendían a los autores consagrados y abjuraban de la nueva estética de Baudelaire, Verlaine o Rémy de Gourmont (1999:282).

La melancolía en el trabajo de Huysmans se instala en las ideas decadentistas y en la expresión dandy de las mismas. Esta corriente finisecular mezcla la moral, la religión y las sensaciones, así como la acedia, es decir, la tristeza religiosa medieval; su mayor representante dentro del Decadentismo fue Baudelaire: "Y, por supuesto, el brillo de la acedia ilumina a Charles Baudelaire. En Mi corazón al desnudo, Cohetes y Las flores del mal, hallamos gran proximidad con la fenomenología del acidioso; de hecho, en este último texto el autor coloca su poesía bajo el signo de la acedia (spleen, ennui). Y la misma figura del Dandy constituye de algún modo una reencarnación del acidioso" (Salas, 2006:148). De ahí que se pueda tomar la acedia medieval como núcleo del estudio del Decadentismo en este autor y considerar la subversión de la religión como punto de partida: "En verdad que no me equivocaba al considerar el dandismo como una especie de religión" (Baudelaire, 1994:109). Se puede señalar que Huysmans, con esta obra, nos hace partícipes de la aparición de un nuevo culto, de una nueva religión que tiene como núcleo la adoración esteticista del arte en su versión decadente, o sea, en la práctica de una religión subvertida donde el mal hace las veces del bien. El trasfondo se encuentra en la acedia que sufrían los monjes en la Edad Media y que los dandis y decadentes sienten como suya. Por eso, se debe acudir al concepto medieval de la acedia, tal como la sugiere Giorgio Agamben, a saber, como en la ausencia de un objeto representable y con ello, la tristeza sin causa y sin objeto definido (2006). El dandismo acidioso para Huysmans (como para Baudelaire), es una religión acompañada del "diablo meridiano" o sea del Mal, enfermedad que padecen los seres humanos tocados con la magia del ingenio y que ya afectaba a los religiosos en el pasado: 
Para empezar diremos que en las nociones de gran ennui y de aburrimiento profundo hemos de reconocer variaciones y entonaciones de una misma cuestión que transita por la Edad Media y el Renacimiento, a saber, la acedía (tristitia, taedium vitae, desidia, incuria), en la cual los padres de la Iglesia reconocen un mal peor que la peste, el más letal de los vicios y para el cual no hay perdón posible. Agobiado por sus cuitas, el monje cenobita no logra acomodo en ningún lugar; no logra ninguna comodidad en su celda, mira por la ventana y le parece que el sol se ha detenido, lo encuentra indudablemente estático; va y viene en medio de sus meditaciones hasta caer inexorablemente en la incredulidad, el desaliento, el torpor, la desesperanza (Salas, 2006:141).

Respecto a la religiosidad subvertida del duque Des Esseintes, se puede señalar que vive de forma similar a los monjes medievales, acompañado exclusivamente de dos siervos con los que no habla porque ha impuesto un "voto de silencio" tácito. En sus aposentos, ha colocado un altar donde tiene las "sagradas escrituras", es decir, los poemas de Baudelaire, copiados sobre auténtico pergamino en letras de misal. Baudelaire es el pontífice de una iglesia y el Decadentismo esteta es la religión del mal, donde no hay lugar para Jesucristo: "O sea, el monje acédico se retrae, casi con náusea, del mismo Dios" (Salas, 2006:145). Esta religión sin dios no es para todos, es un credo al que solo unos pocos elegidos pueden pertenecer, una nueva religión reservada a los espíritus aristocráticos, refinados, y sensibles que creen en el poder del arte y profesan un misticismo estético y un dogma religioso que, en vez del bien, instaura el mal. El "demonio meridiano" ha ganado la partida, y sus adeptos acidiosos se dejan poseer por él. El duque Des Esseintes hace las veces de sacerdote del Decadentismo dandy: "había mandado habilitar un gran salón destinado a recibir a sus proveedores. Estos iban entrando, se instalaban uno junto a otro en una hilera de sillas de coro de iglesia, y entonces él subía a un púlpito magistral y les predicaba un sermón sobre el dandismo" (Huysmans, 1984:130).

Al igual que los monjes acidiosos, la enfermedad melancólica también ataca al duque. La muerte, para ambos, es un oasis, un lugar anhelado que calmará la sed de paz que, de manera angustiosa e infinita, sufren sin remedio. El dogma alterado no insufla vida a sus devotos, sólo exhibe muerte. Un ejemplo son los banquetes que el duque ofrecía: uno de ellos fue un festín funerario donde se interpretaba una marcha fúnebre y los invitados eran atendidos por mujeres negras desnudas. La muerte está unida a la oscuridad, de hecho, es la oscuridad eterna. Y Des Esseintes se encuentra muy a gusto permaneciendo entre tinieblas y sintiendo el oscuro hecho luctuoso muy de cerca; por eso, no desea ver la claridad del sol y deja que la luz del exterior entre a través de los ventanales de forma indirecta; debe ser filtrada para dejar solo pasar una suave luminosidad: "Las ventanas cuyos cristales ásperos y azulados, salpicados de fondos de botella punteados de oro, interceptaban la vista del exterior y sólo dejaban penetrar una luz tenue" (Huysmans, 1984:136).

Como los monjes acidiosos, el dandy se encuentra con la contradicción de amar la soledad, pero sentirse angustiado dentro de ella. Des Esseintes no quiere tener ningún tipo de comunicación con el exterior, se encierra en sí mismo y no permite que nada le moleste: "La décadence, plus qu une mode littéraire ou esthétique, est un art de vivre qui distingue le décadent de ses contemporains et lui attribue dans son époque une manière toute subjective de concevoir l'espace et le temps" (Kociubinska, 2011:39). Incluso dentro del edificio no se permiten ruidos, los mayordomos llevan zapatillas de fieltro para que no se oigan las 
pisadas y el duque manda engrasar las bisagras de las puertas para que no produzcan sonidos. Ni siquiera el duque se dirige a ellos verbalmente, utiliza los toques de una campana al igual que se hace en los monasterios. El rígido horario de los religiosos es seguido por el duque de forma subvertida, aunque igualmente estricta: a las cinco de la tarde se sirve el desayuno, a las once de la noche la cena y las cinco de la mañana es la hora de acostarse.

En la sociedad burguesa solo se encuentra utilitarismo y mediocridad, así que el duque necesita manipular todo aquello que se halla a su alrededor puesto que la realidad es totalmente decepcionante. El cubano Julián del Casal señala que al igual que Des Esseintes, el propio Huysmans "odia, por encima de todo, la época en que vive, considerando que, tanto desde el punto de vista artístico, como desde el punto de vista religioso, es la más mezquina, la más abyecta, la más infame, la más abominable de todas" (citado en Gullón, 1980:454). Por eso, modifica su entorno de forma efectiva y lo adapta a su gusto y, de esa manera, reconstruye artificialmente su mundo externo. Por ejemplo, recrea el camarote de un barco en sus aposentos y los peces que nadan en su acuario: "Se imaginaba entonces que se encontraba en la entrecubierta de un navío y contemplaba con curiosidad unos maravillosos peces mecánicos, construidos como piezas de relojería" (Huysmans, 1984:140). Julián del Casal, siguiendo los dictados decadentistas de Baudelaire (Les paradis artificiels) y $\mathrm{Hu}-$ ysmans, suscribe la supremacía de la belleza artificial: "La Belleza artificial, de cualquier orden que sea, por ser la única que no cambia, que no muere, que no engaña jamás" (Citado en Gullón,1980:454). La belleza natural (por ejemplo, en El retrato de Dorian Grey), termina por entrar en decadencia y destruirse, en cambio, la belleza artificial se mantiene, dotando al melancólico de la ilusión de una vida y belleza eternas.

Casiano establece una filiae acediae que es la evagatio mentis. Agamben la define como "la fuga del ánimo ante sí mismo y el inquieto discurrir de fantasía en fantasía" (2006:27). La mente del acidioso vagaba dulcemente alejándose a lugares en los que le gustaría estar o complaciéndose con imágenes en muchas ocasiones prohibidas: "Imaginación y deseo eran para el clérigo y el monje medievales batalla cotidiana de su melancolía —afirma C. Gurméndez-. Su pereza se complacía en idear deliciosas imágenes de placer inasequibles" (1994:46). Al duque Jean Floressas des Esseintes le ocurre exactamente igual, gracias a la sugestión que le proporciona el arte extravagante puede escapar a cualquier lugar, tanto lícito como ilícito y como los monjes "una vez más se sentía obsesionado no por la religión misma, sino por la malicia de los actos libertinos y de los pecados que ella condena" (Huysmans, 1984:231). Artificialmente decora su habitación para que parezca la celda de un monasterio; lo que en el pasado fue una alcoba para las relaciones amorosas, es en la actualidad un oratorio: 'La foi religeuse n'est plus qu'un souvenir nostalgique, l'amour n' est que la soumission inconsciente aux volontés aveugles de l' instinct de survie de l' espèces" (Kociubinska, 2011: 39). Se sentía hermano de pensamiento de aquellos lejanos fantasmas acidiosos que su imaginación traía de lugares remotos en el tiempo y en el espacio: "Como un ermitaño, se encontraba maduro para el recogimiento, cansado de la vida y no esperando ya nada nuevo de ella; al igual que un monje también se sentía abrumado por un inmenso hastío, por una necesidad de aislamiento, por un deseo de no tener nada en común con los profanos que eran, según él, los utilitarios y los imbéciles" (Huysmans, 1984:192). Pero esta religión, obviamente, se queda fuera de la religión oficial carac- 
terizada por la sustentación en los dogmas cristianos. De ahí que Salas subraye que el cenobita entristecido "sabe que Dios ha muerto" (2006: 147). El duque, ya de joven, pierde la fe debido a las contradicciones intrínsecas que encuentra en las creencias cristianas; sólo era seguidor de su propio credo esteta ya que "no sentía ningún tipo de vocación por el estado de gracia" (Huysmans, 1984:192).

Del monje le separa el gusto que siente por el arte raro, extraño, especial. Al igual que Baudelaire, la belleza, ya sea en el arte o en la vida, tiene que poseer algo extravagante y decadente que le ayude a "escapar de las vulgaridades y del mundo" (Huysmans, 1984:257). Julián del Casal, en un artículo dedicado al autor francés, señala: "La Belleza, que encarna lo raro, es la musa de sus ditirambos, y la Fealdad, que se personifica en lo vulgar, la nodriza de sus diatribas. Puede decirse que lo feo, todavía más que lo bello, lo hiere intensamente, exacerbando de tal manera su sistema nervioso, que nos describe luego con todos sus detalles" (citado en Gullón, 1980:192). Por eso, al igual que Baudelaire, a Des Esseintes le gustan los libros y flores raras, objetos que no se encuentran fácilmente; es un sibarita que goza de todos los placeres, que se siente hastiado de la vida y necesita experimentar lo "misterioso" de la existencia: "Para el deleite de su espíritu y el placer de sus ojos, buscó por lo tanto algunas obras sugestivas y evocadoras que tuvieran el poder de sumergirle en un mundo desconocido, de aportarle revelaciones ocultas, de estremecerle el sistema nervioso mediante eruditas histerias" (Huysmans, 1984:176). El duque ama el arte decadente; por ejemplo, la decadencia de la literatura latina: "Á rebours de Joris Karl Huysmans es un ejemplo ilustrativo del discurso de la Décadence en la literatura" (Sverdloff, 2013:146). Incluso él mismo se siente decadente, raro y enfermo. Las flores exóticas que hace traer de los invernaderos de Chatillon son una representación de su propia persona. Son flores raras y de apariencia enfermiza que nos recuerda el título de la obra de Baudelaire (Le fleurs du mal): "La mayoría, como si estuvieran carcomidas por la sífilis y la lepra, mostraban una carne lívida, amoratada por la roséola, o adamascada por los herpes" (Huysmans, 1984:218). Según Julián del Casal, a Huysman le place "la naturaleza enferma, porque entonces se reviste de cierto encanto melancólico que se armoniza con sus ideas o le endulza sus sufrimientos" (citado en Gullón, 1980:454).

Los monjes medievales veían a la mujer unida al sexo, al pecado y a la enfermedad. El duque pasaba horas mirando el cuadro de Moreau en el que se hallaba retratada Salomé, mujer vista por la historia como una de las féminas más crueles que han existido: "El personaje de Salomé, que tanta fascinación ha ejercido sobre los artistas y los poetas, obsesionaba desde hacía años a Des Esseintes. ¡Cuántas veces había leído en la vieja Biblia de Pierre Variquet, traducida por los doctores en teología de la Universidad de Lovaina, el Evangelio de San Mateo que cuenta, con ingenuas y breves frases, la degollación del Precursor" (Huysmans, 1984:178). Con esas breves frases, la imaginación de los monjes acidiosos, al igual que la del duque, volaba gracias a "la fuga ánimo ante sí, el inquieto discurrir sin la mínima dirección de fantasía en fantasía" (Salas, 2006: 143). Cada una de las vetas del Decadentismo nos conduce sin remisión a la acedia moderna, profundamente enraizada en la medieval. Los monjes acidiosos dejaban flotar su imaginación, en muchas ocasiones, hacia imágenes eróticas de fascinantes mujeres uniendo de forma arquetípica el misticismo con el satanismo: 
Aseméjase su espíritu, en tales horas — comenta Julián del Casal-, a un tabernáculo profanado, donde manos infernales guardaron hostias consagradas y monedas de oro, custodias inmaculadas y puñales ensangrentados, mitras episcopales y gorros frigios, estolas de canónigos y bandas de bailarinas, cálices benditos y frascos de afrodisíacos (Gullón,1980:454).

Cercano al acidioso se encuentra el "typus melancholicus" que posee las mismas características y se caracteriza también por ostentar una especial hipersensibilidad: "estado de hipersensibilidad del aparato emocional central" (Tellenbach, 1976:86). En el duque Jean Floressas des Esseintes se observa claramente este rasgo personal. El decadente está dotado de la capacidad de percibir "la cadencia particular de cada color" (Huysmans, 1984:134) o los matices casi imperceptibles de una obra de arte. Incluso, gracias a esta hipersensibilidad, se le rebelan las correspondencias entre sentidos por muy sutiles que sean: "según él, el sabor de cada licor se correspondía con el sonido de un instrumento preciso. El curaçao seco, por ejemplo, contenía en su sabor el sonido del clarinete, cuyo tono es agridulce y aterciopelado; el kummel correspondía al oboe, cuyo timbre sonoro tiene una resonancia nasal" (Huysmans, 1984:170). Afirma Brunel:

Le romancier d'A rebours a poussé jusqu'aux extrêmes de la minutie et de la sophistication le détail concernant ce qui reste, heureusement, une simple création de papier. Mais c'est un véritable plaisir musical que son héros, des Esseintes, tire de cet orgue à bouche, tout aussi bien un orchestre de saveurs. Jouant des étiquettes qui distinguent les tiroirs du buffet d' orgue, il recherche, en ultrabaudelairien, une correspondance entre le goût de chaque liqueur et le son d'un instrument (2007:149).

Pero la hipersensibilidad tiene un lado muy negativo: la sensibilidad del duque es refinada, pero a la vez, atormentada, mórbida, voluptuosa y turbulenta, tan cercana a la locura como a la melancolía. No encuentra un momento de paz, la inquietud y la angustia le persiguen y el arte, que en un primer lugar le ayuda a desasirse del spleen, termina, como avisaba Ficino (2006), abocándole a la más profunda melancolía. La soledad le rodea en un halo de locura: "la soledad había alterado su cerebro, del mismo modo que un narcótico. Después de haberle excitado y estimulado en un principio, le producía una sensación de desgana y abatimiento" (Huysmans, 1984: 200). La situación empeoraba debido a un tenaz insomnio: "Permanecía durante horas enteras echado sobre la cama, acosado, unas veces, por insomnios persistentes y febriles agitaciones, y sumergido, otras en abominables sueños" (Huysmans, 1984: 228). El insomnio y el miedo son dos de los síntomas más conocidos de la enfermedad de la bilis negra. La situación se hizo insostenible: "Su angustia se acrecentó, pero desgraciadamente no llegaba a encontrar ningún remedio apropiado para combatir su inexorable enfermedad (Huysmans, 1984:228). El médico del duque, al ver su aspecto, le instó a volver a París y dejar la perniciosa soledad en la que se enontraba. Des Esseintes accede y dejándose caer en un sillón exclama: "Todo se ha terminado; como un maremoto, las olas de la mediocridad humana suben hasta el cielo y van a sepultar el refugio cuyos diques estoy abriendo, muy a pesar mío. ¡Ah! ¡Me falta valor y me duele el alma!" (Huysmans, 1984: 366).

La acidia medieval no se eclipsa en los monasterios de la Edad Media sino que se vigoriza en el Renacimiento, momento en el que se pone en relación la antigua teoría humo- 
ral con el genio melancólico (Aristóteles, El hombre de genio y la melancolía, 2007), y más adelante, vuelve en una de las renovaciones más problemáticas de la modernidad: el Decadentismo finisecular y el mal du siècle. La modernidad y la postmodernidad beben de esa fuente que inspiró a los genios de su época, como Strindberg o Rouault, y que continuará manando en posteriores generaciones.

\section{BIBLIOGRAFÍA}

Agamben, Giorgo (2006): Estancias. La palabra y el fantasma en la cultura occidental, Valencia, Pre-Textos.

ARISTóteles (2007): El hombre de genio y la melancolía (problema XXX), Barcelona, Acantilado.

Balzac, Baudelaire, Barbey D’Aurevilly (1994): El dandismo, Barcelona, Anagrama.

Brunel, Pierre (2007): «Musique des sens, de Baudelaire à Huysmans». Revista de Filología Románica, anejo V, págs.143-151. Marsilio

Ficino, Marsilio (2006) Tres libros sobre la vida, Madrid, Asociación Española de Neuropsiquiatría.

GonZÁlez, Miguel Ángel (1999): «Joris Karl Huysmans y su visión de la literatura latina». Cuadernos de Filología Clásica, Estudios Latinos, 17, págs. 279-292.

Gullón, RicARdo (1980): El modernismo visto por los modernistas, Barcelona, Labor.

Gurméndez, Carlos (1994): La melancolía, Madrid Espasa, Calpe.

Huysmans, Joris-Karl (1984): A contrapelo, Madrid, Cátedra.

KociubinsKa, Edyta (2011): «Espace et temps entre les mains d'un esthète décadent: Á rebours de J.-K. Huysmans». Études Romanes de Brno, 32, págs. 39-46.

Salas, María Cecilia (2006): El afecto sin objeto y la escritura fragmentaria. Una lectura del desasosiego pessoano. Madrid, Universidad Autónoma de Madrid.

Sverdloff, Mariano (2013) «Apropiaciones de la latinidad 'decadente' en el siglo XIX: el caso de $A ́$ rebours de J.K. Huysmans». Fortunatae, 24, págs. 141-154.

Tellenbach, Hubertus (1976): Melancolía, Madrid, Morata. 